\title{
PEMBUATAN SEDIAAN MASKER KETIAK DAUN SIRIH (Piper betle, L), LIDAH BUAYA (Aloe vera, L) DAN MADU UNTUK MENGATASI BAU BADAN
}

\author{
Farah Sulistyaningtyas ${ }^{1}$, Ida Hanifah ${ }^{2}$ \\ ${ }^{1}$ Program Studi Farmasi / Politeknik META Industri Cikarang / \\ farahsulistyaningtyas@politeknikmeta.ac.id \\ 2 Program Studi Farmasi / STIKes Holistic Purwakarta / \\ IdaHanifah@gmail.com
}

\begin{abstract}
A research has been done with the title of "The Production Armpit Mask Supply From Betel Leaf (Piper betle, L), Aloe Vera (Aloe vera, L) And Honey To Overcome Body Odor" which is purposed to find out the production of armpit mask supply, observe the research in organoleptic terms, $\mathrm{pH}$ level, observation of the supply inside room temperature and have 3 (three) container supply in different condition which is opened, closed and with silica gel. The method used in this research is action research. Produced in the total of 9 pieces of sample which is divided into 3 different composition. Sample I contains 3,15 g of betel leaf; 11,85 $\mathrm{g}$ of aloe vera; $1 \mathrm{ml}$ honey, sample II contains 3,15 $\mathrm{g}$ of betel leaf; 11,85 $\mathrm{g}$ of aloe vera; $2 \mathrm{ml}$ honey, sample III contains $3,15 \mathrm{~g}$ of betel leaf; $11,5 \mathrm{~g}$ of aloe vera; $3 \mathrm{ml}$ honey. The result of this research shows that sample kept inside a closed container and container with silica gel does not undergo any significant change organoleptically for three weeks and possess an average of 3,8; 3,7; and 3,6 pH levels. While the best supply is sample I which is kept inside closed container with 3,8 pH value.
\end{abstract}

Keywords: Armpit Mask, Betel Leaf, Aloe Vera, Honey, Body Odor

\begin{abstract}
ABSTRAK
Telah dilakukan penelitian dengan judul "Pembuatan Sediaan Masker Ketiak Daun Sirih (Piper betle, L), Lidah Buaya (Aloe vera, L) dan Madu Untuk Mengatasi Bau Badan" yang memiliki tujuan mengetahui cara pembuatan sediaan masker ketiak, mengamati penelitian dalam segi organoleptik, kadar $\mathrm{pH}$, pengamatan sediaan dalam suhu ruangan dan memiliki 3 (tiga) sediaan wadah dalam kondisi berbeda yaitu tertutup, terbuka dan dengan silica gel. Metode yang dilakukan adalah action research. Dibuat dalam total keseluruhan 9 buah sampel yang dibagi 3 komposisi yang berbeda. Sampel I mengandung daun sirih $3,15 \mathrm{~g}$; lidah buaya 11,85 g; madu 1 $\mathrm{ml}$, sampel II mengandung daun sirih $3,15 \mathrm{~g}$; lidah buaya $11,85 \mathrm{~g}$, madu $2 \mathrm{ml}$, dan sampel III mengandung daun sirih $3,15 \mathrm{~g}$; lidah buaya $11,5 \mathrm{~g}$; madu $3 \mathrm{ml}$. Hasil dalam penelitian ini menunjukkan bahwa sampel yang disimpan dalam wadah tertutup dan wadah dengan silica gel tidak mengalami perubahan yang signifikan secara organoleptik selama tiga minggu dan memiliki kadar rata-rata $\mathrm{pH}$ 3,8, 3,7 dan 3,6. Sedangkan sediaan yang paling baik adalah sampel I yang disimpan dalam wadah tertutup dengan nilai $\mathrm{pH} 3,8$.
\end{abstract}

Kata Kunci: Masker Ketiak, Daun Sirih, Lidah Buaya, Madu, Bau Badan

\section{PENDAHULUAN}

Berkeringat merupakan salah satu cara alami tubuh untuk menurunkan suhu tubuh. Cuaca yang panas akan membuat seseorang berkeringat dan kadang produksinya berlebih pada sebagian orang. Bagi seseorang yang memiliki produksi keringat berlebih masalah utama yang biasanya timbul adalah bau badan, dimana hal tersebut dapat menyebabkan seseorang menjadi kurang 
percaya diri didepan umum dan berusaha untuk mengatasinya. Faktanya, bau yang dihasilkan sebenarnya bukan berasal dari keringat yang keluar. Namun, Wijayanti (2012) mengungkapkan bahwa bau kurang sedap yang keluar ini terjadi akibat bakteri yang bercampur dengan keringat. (Wijayanti, 2012 dalam Virgianti, dkk). Kosmetik adalah bahan atau campuran bahan yang digunakan pada permukaan kulit manusia dengan maksud untuk membersihkan, memelihara, menambah daya tarik dan mengubah rupa dan tidak termasuk golongan obat. Menurut MRPK (2017) masker kecantikan berarti kosmetik yang berwujud cairan (atau bahan lunak) yang dioleskan untuk membersihkan dan mengencangkan kulit. (MRPK, 2017).

Dalam penanganan bau badan, produk sintetis seperti deodorant dan antiperspirant sudah umum dipakai oleh masyarakat. Deodorant bekerja dengan cara menghambat pertumbuhan mikroorganisme yang ditemukan pada ketiak sedangkan antiperspirant bekerja dengan cara mengurangi sekresi keringat melalui sumbatan pada saluran keringat. Dampak buruknya, menurut rumor bahan kimia dalam antiperspirant yang diserap melalui kulit dapat mengganggu sirkulasi getah bening sehingga menyebabkan terbentuknya toksin di payudara, dan akhirnya menyebabkan kanker payudara. (Rozi, 2017). Akibat dampak buruk antiperspirant yang dapat menyebabkan kanker, diperlukan suatu produk yang aman bagi masyarakat sebagai alternatif untuk mengatasi bau badan berbahan dasar herbal. Indonesia sebagai salah satu negara dengan kekayaan hayatinya memiliki sejumlah tumbuhan berkhasiat yang sudah turun temurun digunakan sebagai obat maupun kosmetik. Penelitian menunjukkan bahwa daun sirih ( Piper betle, L) dan lidah buaya ( Aloe vera, L) mengandung senyawa yang dapat dimanfaatkan sebagai antibakteri alami. Sirih mengandung minyak atsiri, dimana sepertiga dari minyak atsiri tersebut terdiri dari phenol dan sebagian besar adalah kavikol. Kavikol inilah yang memberikan bau khas daun sirih dan memiliki daya pembunuh bakteri lima kali lipat dari phenol biasa. (Moeljanto, 2003). Dengan adanya penelitian mengenai daun sirih dan lidah buaya yang menunjukkan khasiatnya sebagai antibakteri, peneliti tertarik untuk membuat suatu sediaan antibau badan berupa masker khusus ketiak yang mengandung daun sirih dan lidah buaya dengan tambahan madu yang berfungsi sebagai pengawet alami.

\section{METODE PENELITIAN}

Pendekatan penelitian yang digunakan adalah pendekatan kualitatif yaitu pendekatan yang meneliti kualitas hubungan, aktivitas, situasi, atau berbagai material. Pendekatan kualitatif lebih menekankan pada deskriptif holistik, yang menjelaskan secara detil tentang kegiatan atau situasi apa yang sedang berlangsung daripada membandingkan efek perlakuan tertentu, atau menjelaskan tentang sikap atau perilaku orang. (Wahab, 2014)

Jenis penelitian yang digunakan adalah penelitian action research, yaitu suatu penelitian informal, kualitatif, formatif, subjektif, interpretif, reflektif dan suatu model penelitian pengalaman, di mana semua individu diibaratkan dalam studi sebagai peserta yang mengetahui dan menyokong. (Hopkin dalam Sarwono, 2006)

Penelitian ini dilakukan dengan membuat sediaan sebanyak 9 (sembilan) buah sampel yang dibagi menjadi 3 komposisi sampel yang berbeda. Sampel I mengandung daun sirih 3,15 g; lidah buaya $11,85 \mathrm{~g}$; madu $1 \mathrm{ml}$, sampel II mengandung daun sirih $3,15 \mathrm{~g}$; lidah buaya $11,85 \mathrm{~g}$; madu $2 \mathrm{ml}$, dan sampel III mengandung daun sirih 3,15 g; lidah buaya 11,85 g; madu $3 \mathrm{ml}$. Sampel tersebut disimpan dalam 3 (tiga) wadah penyimpanan yang berbeda, yaitu wadah tertutup, wadah terbuka dan wadah dengan silica gel. Masing-masing wadah penyimpanan terdiri dari 3 (tiga) buah sampel dan disimpan dalam suhu ruangan $28{ }^{\circ} \mathrm{C}$ selama tiga minggu dan diamati perkembangan yang terjadi lalu dicatat hasilnya. 


\section{HASIL DAN PEMBAHASAN}

\subsection{HASIL PEMBUATAN SEDIAAN}

Dari $1 \mathrm{~kg}$ daun sirih (Piper betle, L) segar diperoleh serbuk sirih sebanyak 175,561 gram dengan persentase rendemen sebesar 17,5\%. Sedangkan daging daun lidah buaya (Aloe vera, L) yang diperoleh sebelum diproses adalah 176,354 gram dan setelah diproses adalah 163,557 gram. Masker dibuat menjadi 3 (tiga) kelompok dengan masing-masing kelompok dibuat 3 (tiga) sampel untuk diuji pada kondisi penyimpanan yang berbeda. Daun sirih dan lidah buaya disamakan untuk semua sampel, yaitu daun sirih sebanyak 3,15 gram dan lidah buaya sebanyak 11,85 gram. Sedangkan komposisi madu pada sampel dibedakan, dimana Sampel I mengandung madu $1 \mathrm{ml}$, Sampel II mengandung madu $2 \mathrm{ml}$ dan Sampel III mengandung madu $3 \mathrm{ml}$. Ketiga sampel tersebut kemudian disimpan dalam 3 (tiga) wadah penyimpanan yang berbeda dengan masing-masing wadah penyimpanan berisi 1 buah sampel dari masing-masing komposisi sampel. Maka total satu wadah penyimpanan adalah 3 buah sampel, dan total seluruh masker yang dibuat adalah 9 (sembilan) buah sediaan. Adapun perbedaan komposisi sampel dan wadah penyimpanan dapat dijelaskan dalam tabel sebagai berikut.

Tabel 3.1 Komposisi Sediaan Masker dan Wadah Penyimpanan

\begin{tabular}{|c|c|c|c|c|}
\hline \multirow{2}{*}{$\begin{array}{c}\text { Nama } \\
\text { Sampel }\end{array}$} & Komposisi Sampel & \multicolumn{3}{|c|}{ Wadah Penyimpanan } \\
\cline { 3 - 5 } & Tertutup & $\begin{array}{c}\text { Wadah } \\
\text { Terbuka }\end{array}$ & $\begin{array}{c}\text { Wadah } \\
\text { dengan Silica } \\
\text { Gel }\end{array}$ \\
\hline Sampel I & $\begin{array}{l}\text { Daun sirih 3,15 g ; Lidah } \\
\text { buaya 11,85 g; Madu 1 ml }\end{array}$ & 1 buah & 1 buah & 1 buah \\
\hline Sampel II & $\begin{array}{l}\text { Daun sirih 3,15 g ; Lidah } \\
\text { buaya 11,85 g; Madu 2 ml }\end{array}$ & 1 buah & 1 buah & 1 buah \\
\hline Sampel III & $\begin{array}{l}\text { Daun sirih 3,15 g ; Lidah } \\
\text { buaya 11,85 g; Madu 3 ml }\end{array}$ & 1 buah & 1 buah & 1 buah \\
\hline & Total & 3 buah & 3 buah & 3 buah \\
\hline
\end{tabular}

Ketiga komposisi sampel dengan perbedaan wadah penyimpanan tersebut dilakukan pengujian organoleptik selama tiga minggu pada suhu ruangan $28{ }^{\circ} \mathrm{C}$.

\subsection{HASIL PENGUJIAN SEDIAAN}

Pengujian yang dilakukan adalah pengujian organoleptik yang meliputi bentuk, bau, rasa dan warna dari sediaan yang disimpan selama 3 minggu pada suhu ruangan $28{ }^{\circ} \mathrm{C}$. Selain pengujian organoleptik dilakukan pula pengujian $\mathrm{pH}$ dengan menggunakan alat $\mathrm{pH}$ meter.

a. Hasil Uji Organoleptik

Tabel 3.2.1 Perbedaan Organoleptik Sampel

\begin{tabular}{|l|c|c|c|c|}
\hline \multirow{2}{*}{ Jenis } & \multicolumn{4}{|c|}{ Organoleptik } \\
\cline { 2 - 5 } & Bentuk & Bau & Rasa & Warna \\
\hline Sampel I & Kental & Bau khas sirih & Sedikit pahit & Cokelat kehitaman \\
\hline Sampel II & Sedikit encer & Bau khas sirih & Sedikit pahit & Cokelat kehitaman \\
\hline Sampel III & Lebih encer & Bau khas sirih & Sedikit pahit & Cokelat kehitaman \\
\hline
\end{tabular}


Tabel 3.2.2 Sediaan yang Disimpan dalam Wadah Tertutup dan Wadah Dengan Silica Gel Setelah Tiga Minggu

\begin{tabular}{|c|c|c|c|c|}
\hline \multirow{2}{*}{$\begin{array}{c}\text { Jenis } \\
\text { Sampel }\end{array}$} & \multirow{2}{*}{ Organoleptik } & \multicolumn{3}{|c|}{ Minggu Ke- } \\
\hline & & Minggu ke- 1 & Minggu ke- 2 & Minggu ke- 3 \\
\hline \multirow[t]{4}{*}{ Sampel I } & Bentuk & Kental & Kental & Kental \\
\hline & $\mathrm{Bau}$ & Sedikit pahit & Sedikit pahit & Sedikit pahit \\
\hline & Rasa & Bau khas sirih & Bau khas sirih & Bau khas sirih \\
\hline & Warna & Cokelat kehitaman & Cokelat kehitaman & Cokelat kehitaman \\
\hline \multirow[t]{4}{*}{ Sampel II } & Bentuk & Sedikit encer & Sedikit cair & Sedikit cair \\
\hline & $\mathrm{Bau}$ & Sedikit pahit & Sedikit pahit & Sedikit pahit \\
\hline & Rasa & Bau khas sirih & Bau khas sirih & Bau khas sirih \\
\hline & Warna & Cokelat kehitaman & Cokelat kehitaman & Cokelat kehitaman \\
\hline \multirow[t]{4}{*}{ Sampel III } & Bentuk & Lebih encer & Lebih encer & Lebih encer \\
\hline & Bau & Sedikit pahit & Sedikit pahit & Sedikit pahit \\
\hline & Rasa & Bau khas sirih & Bau khas sirih & Bau khas sirih \\
\hline & Warna & Cokelat kehitaman & Cokelat kehitaman & Cokelat kehitaman \\
\hline
\end{tabular}

Tabel 3.2.3 Sediaan yang Disimpan dalam Wadah Terbuka Setelah Tiga Minggu

\begin{tabular}{|c|c|c|c|c|}
\hline \multirow{2}{*}{$\begin{array}{c}\text { Jenis } \\
\text { Sampel }\end{array}$} & \multirow{2}{*}{ Organoleptik } & \multicolumn{3}{|c|}{ Minggu Ke- } \\
\hline & & Minggu ke- 1 & Minggu ke- 2 & Minggu ke- 3 \\
\hline \multirow[t]{4}{*}{ Sampel I } & Bentuk & Kering retak & Kering retak & Kering retak \\
\hline & $\mathrm{Bau}$ & Sedikit pahit & Sedikit pahit & Sedikit pahit \\
\hline & Rasa & Bau khas sirih & Bau khas sirih & Bau khas sirih \\
\hline & Warna & Cokelat kehitaman & Hijau tua & Hijau tua \\
\hline \multirow[t]{4}{*}{ Sampel II } & Bentuk & Kering retak & Kering retak & Kering retak \\
\hline & $\mathrm{Bau}$ & Sedikit pahit & Sedikit pahit & Sedikit pahit \\
\hline & Rasa & Bau khas sirih & Bau khas sirih & Bau khas sirih \\
\hline & Warna & Cokelat kehitaman & Cokelat & Cokelat \\
\hline \multirow[t]{4}{*}{ Sampel III } & Bentuk & Kering retak lembab & Kering retak & Kering retak \\
\hline & Bau & Sedikit pahit & Sedikit pahit & Sedikit pahit \\
\hline & Rasa & Bau khas sirih & Bau khas sirih & Bau khas sirih \\
\hline & Warna & Cokelat kehitaman & Cokelat kehitaman & Cokelat tua \\
\hline
\end{tabular}




\subsection{HASIL PENGUJIAN pH}

Tabel 3.3.1 Hasil Pengujian pH Rata-Rata Setiap Sampel

\begin{tabular}{|c|c|}
\hline Sampel & pH rata-rata \\
\hline Sampel I & 3,8 \\
\hline Sampel II & 3,7 \\
\hline Sampel III & 3,6 \\
\hline pH rata-rata total & 3,7 \\
\hline
\end{tabular}

\subsection{PEMBAHASAN}

Dalam pembuatan sediaan masker digunakan bahan utama yaitu daun sirih (Piper betle, L) segar sebanyak $1 \mathrm{~kg}$. Daun sirih tersebut dikeringkan dengan cara disangrai, lalu kemudian dijadikan serbuk dengan tujuan agar mempermudah pencampuran daun sirih dengan bahan lainnya. Selain itu pengeringan ini juga bertujuan untuk mengurangi potensi tumbuhnya mikroorganisme sehingga daun sirih dapat disimpan dalam jangka waktu yang lama. Dalam pengeringan, secara langsung akan mengurangi kadar air dalam bahan, dimana kadar air yang baik untuk simplisia adalah kurang dari 10\%. Namun dalam penelitian tidak dilakukan pengujian kadar air, sehingga tidak diketahui apakah kadar air serbuk sirih sudah memenuhi standar atau belum. Dari $1 \mathrm{~kg}$ daun sirih segar diperoleh serbuk daun sirih sebanyak 175,651 gram dengan persentase rendemen sebesar 17,5\%.

Lidah buaya yang digunakan dihaluskan dengan menggunakan blender, dimana hal ini bertujuan untuk mempermudah pencampuran lidah buaya dengan bahan lainnya. Setelah proses pemblenderan, lidah buaya akan menghasilkan buih diatas permukaannya yang dapat dihilangkan dengan cara disimpan ke dalam lemari pendingin selama beberapa saat. Dalam penelitian, lidah buaya disimpan selama 2 jam dengan suhu yang konstan. Lidah buaya disimpan pada bagian tengah lemari pendingin agar suhu terukur konstan $1{ }^{\circ} \mathrm{C}$. Untuk menghilangkan buihnya, sebenarnya lidah buaya dapat disimpan pada suhu ruangan biasa, namun untuk mempercepat pemecahan buih lidah buaya disimpan dalam suhu yang dingin. Setelah didinginkan, lidah buaya tersebut kemudian dipanaskan dengan suhu $35{ }^{\circ} \mathrm{C}$, dimana proses ini dimaksudkan untuk mencegah perubahan warna pada lidah buaya yang disebabkan karena adanya aktivitas enzim fenolase dan oksidase yang inaktif pada suhu $30-40{ }^{\circ} \mathrm{C}$, terdenaturasi pada suhu $40-60{ }^{\circ} \mathrm{C}$ dan terdekomposisi pada suhu diatas $60{ }^{\circ} \mathrm{C}$. Proses pemblenderan menyebabkan bobot lidah buaya menjadi berkurang dari 176,354 gram menjadi 163,557 gram, hal ini dapat diakibatkan karena beberapa bagian lidah buaya yang menjadi cairan juga berubah menjadi buih sehingga menyusutkan bobot lidah buaya. Pengurangan bobot juga dapat diakibatkan karena cairan lidah buaya yang lengket masih menempel pada wadah sehingga agak sulit untuk bersihkan.

Pembuatan masker dibagi menjadi 3 buah komposisi sampel yang berbeda berdasarkan penambahan madunya. Hal ini dimaksudkan untuk mengetahui perbedaan konsistensi diantara ketiga sampel tersebut. Lalu, perbedaan wadah penyimpanan dimaksudkan untuk mengetahui kondisi mana yang paling baik untuk penyimpanan masker, apakah dalam wadah tertutup, wadah terbuka atau wadah dengan silica gel. Fungsi dari silica gel adalah untuk menyerap air, namun perannya dalam penelitian yang dilakukan sepertinya tidak terlalu berpengaruh karena tempat penyimpanan adalah berupa pot salep yang ditutup rapat dan silica gel hanya diletakkan dibagian luar pot.

Penelitian masker yang dilakukan berupa pengujian organoleptik yang meliputi pengamatan bentuk, bau, rasa dan warna yang disimpan pada suhu ruangan $28{ }^{\circ} \mathrm{C}$ serta pengujian $\mathrm{pH}$ yang dilakukan sekali menggunakan alat $\mathrm{pH}$ meter. Setelah tiga minggu pengamatan, diperoleh hasil yaitu sediaan yang disimpan dalam wadah tertutup dan wadah dengan silica gel tidak 
mengalami perubahan yang signifikan, dimana kondisi sampel masih sama seperti hari pertama pengamatan. Sampel I berbentuk kental, Sampel II berbentuk sedikit encer dan Sampel III berbentuk lebih encer. Sedangkan aroma/bau sampel adalah bau khas sirih, dengan rasa sedikit pahit dan berwarna cokelat kehitaman.

Untuk sediaan yang disimpan dalam wadah terbuka setelah pengamatan selama tiga minggu, diperoleh hasil yaitu sudah mengalami perubahan dari hari pertama pengamatan. Pada minggu ke-1 masing-masing sampel mulai berubah bentuk dari bentuk setengah padat menjadi lebih padat karena mengalami pengeringan. Pada hari ke-3 s/d ke-5 Sampel I dan II dalam wadah terbuka semakin mengering dan terdapat retakan pada tengah sediaan yang menyebabkan sediaan terbelah menjadi dua. Sedangkan Sampel III terdapat retakan dengan kondisi lembab dan dingin berbeda dengan kedua sampel lain. Kelembaban yang terjadi disebabkan karena Sampel III mengandung madu yang lebih banyak daripada Sampel I dan II sehingga proses pengeringan Sampel III relatif lebih lambat dari kedua sampel lainnya. Pada minggu ke-2 pengamatan tepatnya hari ke-13, Sampel I mengalami perubahan warna dari cokelat kehitaman menjadi hijau tua dan Sampel II juga mengalami perubahan warna dari cokelat kehitaman menjadi berwarna cokelat. Sedangkan untuk Sampel III tidak terlalu mengalami perubahan yang signifikan dalam segi apapun. Pada minggu ke-3 pengamatan, ketiga sampel menjadi semakin kering. Pada hari ke-15 Sampel III mengalami perubahan warna dari cokelat kehitaman menjadi berwarna cokelat tua. Perubahan yang terjadi pada semua sampel selama penyimpanan disebabkan karena sampel langsung berinteraksi dengan udara, sehingga cairan yang terdapat dalam sampel menguap dan menyebabkan sampel mulai mengering dan mengalami perubahan bentuk, bau dan warna. Hal tersebut menunjukkan bahwa sediaan masker tidak cocok disimpan dalam wadah terbuka. Perbedaan perubahan kondisi yang dialami setiap sampel dikarenakan faktor penambahan madu yang berbeda-beda, dimana dapat disimpulkan bahwa semakin sedikit madu yang ditambahkan maka semakin cepat proses pengeringan terjadi.

Pengujian $\mathrm{pH}$ dilakukan dengan menggunakan alat $\mathrm{pH}$ meter. Hal ini dimaksudkan untuk mengetahui bagaimana tingkat keasaman dari sediaan yang telah dibuat. Beberapa sumber menyatakan bahwa $\mathrm{pH}$ kulit normal berkisar antara 4,5 - 6, atau ada pula yang menyatakan berkisar antara $4-6$. Dari hasil pengujian $\mathrm{pH}$ diperoleh $\mathrm{pH}$ rata-rata setiap sampel adalah, Sampel I $=3,8$, Sampel II $=3,7$ dan Sampel III $=3,6$. Ketiga sampel memiliki $\mathrm{pH}$ yang asam dengan tingkat keasaman yang berbeda-beda. $\mathrm{pH}$ sediaan yang asam disebabkan karena madu yang terkandung dalam sediaan. Madu memiliki sifat asam dengan nilai $\mathrm{pH}$ berkisar antara 3,2 4,5. Selain itu daun sirih juga bersifat asam sehingga hal tersebut dapat mempengaruhi $\mathrm{pH}$ sediaan yang dibuat. Sedangkan perbedaan tingkat keasaman dari masing-masing sampel dapat disebabkan karena penambahan madu yang berbeda-beda, dimana semakin banyak madu yang ditambahkan maka semakin asam pula sediaan masker yang dihasilkan. Dalam penanganan bau badan khususnya pada daerah ketiak, diperlukan $\mathrm{pH}$ yang asam karena bakteri ketiak tidak dapat hidup dalam $\mathrm{pH}$ yang rendah. Sehingga jika ketiak diusapkan $\mathrm{pH}$ yang asam maka hal tersebut dapat menurunkan $\mathrm{pH}$ ketiak dan dapat berpotensi menurunkan jumlah bakteri yang ada pada ketiak. Semua sediaan masker yang telah dibuat tidak ada satupun yang memenuhi kriteria $\mathrm{pH}$ kulit normal karena terlalu asam, namun tingkat keasaman sediaan masih dapat digunakan untuk ketiak karena bakteri ketiak tidak dapat hidup pada $\mathrm{pH}$ yang rendah (asam).

Dari ketiga komposisi sampel sediaan yang telah dibuat dan dilakukan pengujian organoleptik dalam wadah penyimpanan yang berbeda, maka dapat disimpulkan bahwa sediaan yang memiliki organoleptik paling baik adalah Sampel I dengan komposisi: daun sirih sebanyak 3,15 gram, lidah buaya sebanyak 11,85 gram dan madu sebanyak $1 \mathrm{ml}$. Hal tersebut karena Sampel I memiliki tingkat kekentalan yang ideal dan tidak terlalu encer dengan nilai $\mathrm{pH}$ rata-rata sebesar 3,8 . 


\section{KESIMPULAN DAN SARAN}

Sediaan masker ketuak dapat dibuat dengan cara sederhana melalui metode penyangraian yang mengandung bahan daun sirih, lidah buaya dan madu. Masker yang dibuat dibagi menjadi 3 (tiga) buah sampel dengan komposisi daun sirih 3,15 gram, lidah buaya 11,85 gram pada setiap sampelnya dengan penambahan madu yang berbeda-beda. Sampel I mengandung madu sebanyak $1 \mathrm{ml}$, sampel II mengandung madu sebanyak $2 \mathrm{ml}$ dan sampel III mengandung madu sebanyak $3 \mathrm{ml}$. Sediaan yang paling baik berdasarkan hasil pengujian organoleptik dan $\mathrm{pH}$ sediaan adalah sampel I yang disimpan dalam wadah tertutup dengan nilai $\mathrm{pH} 3,8$.

\section{DAFTAR PUSTAKA}

Agoes, H. A. 2010. Tanaman Obat Indonesia. Salemba Medika.

Andareto, O. 2015. Apotik Herbal Di Sekitar Anda. Pustaka Ilmu Semesta, 161-162.

Atmaka, W., Utami, R., \& Raharjo, S. 2011. APLIKASI MADU SEBAGAI PENGAWET DAGING SAPI GILING SEGAR SELAMA PROSES PENYIMPANAN. Jurnal Teknologi Hasil Pertanian, 4(1).

DepKes RI. 2000. Parameter Standar Umum Ekstrak Tumbuhan Obat. Cetakan 1. Jakarta

Felicia, N., \& Felicia, N. 2016. Pengaruh Ketuaan Daun dan Metode Pengolahan Terhadap Aktivitas Antioksidan serta Karakteristik Sensoris Teh Herbal Bubuk Daun Alpukat (Persea americana Mill) (Doctoral dissertation, Universitas Udayana).

Hariyati, L. F. 2010. Aktivitas Antibakteri Berbagai Jenis Madu Terhadap Mikroba Pembusuk (Pseudomonas fluorescens FNCC 0071 dan Pseudomonas putida FNCC 0070) (Doctoral dissertation, Universitas Sebelas Maret).

Imron, S. S. H. 2007, Soebagio, B., \& Agustri, B. Formulasi Deodoran Bentuk Batang (Stick) Dengan Lendir Daun Lidah Buaya (Aloe Vera Linn.). Abstrak.

Irni Furnawanthi, S. P. 2000. Khasiat \& Manfaat Lidah Buaya. AgroMedia.

Khasanah, R. A., Budiyanto, E., \& Widiani, N. 2010. PEMANFAATAN EKSTRAK SEREH (CHYMBOPOGON NARDUS L.) SEBAGAI ALTERNATIF ANTI BAKTERI STAPHYLOCOCCUSEPIDERMIDIS PADA DEODORAN PARFUME SPRAY. Pelita-Jurnal Penelitian Mahasiswa UNY, (1).

Kusantati, H., Prihatin, P. T., \& Wiana, W. 2008. Tata Kecantikan Kulit. Direktorat Pembinaan Sekolah Menengah Kejuruan, Jakarta.

Moeljanto, R. D. 2003. Khasiat \& manfaat daun sirih: obat mujarab dari masa ke semasa. AgroMedia.

Rahmawati, R. 2015. INTERAKSI EKSTRAK DAUN LIDAH BUAYA (Aloe vera L.) DAN DAUN SIRIH (Piper betle L.) TERHADAP DAYA HAMBAT Stapylococcus aureus SECARA IN VITRO. Jurnal Edubio Tropika, 2(1).

Rivai, H., Nanda, P. E., \& Fadhilah, H. 2017. Pembuatan Dan Karakterisasi Ekstrak Kering Daun Sirih Hijau (Piper Betle L.). 